Summer 2011

\title{
Transnational Corporations, Global Competition Policy, and the Shortcomings of Private International Law
}

\author{
Gralf-Peter Calliess \\ Law Department, University of Bremen, Germany, calliess@web.de \\ Jens Mertens \\ University of Bremen
}

Follow this and additional works at: https://www.repository.law.indiana.edu/ijgls

Part of the Business Organizations Law Commons, International Law Commons, and the Transnational Law Commons

\section{Recommended Citation}

Calliess, Gralf-Peter and Mertens, Jens (2011) "Transnational Corporations, Global Competition Policy, and the Shortcomings of Private International Law," Indiana Journal of Global Legal Studies: Vol. 18 : Iss. 2 , Article 8.

Available at: https://www.repository.law.indiana.edu/ijgls/vol18/iss2/8

This Symposium is brought to you for free and open access by the Law School Journals at Digital Repository @ Maurer Law. It has been accepted for inclusion in Indiana Journal of Global Legal Studies by an authorized editor of Digital Repository @ Maurer Law. For more information, please contact rvaughan@indiana.edu.

\section{$\Psi$}

JEROME HALL LAW LIBRARY

INDIANA UNIVERSITY

Maurer School of Law
Bloomington 


\title{
Transnational Corporations, Global Competition Policy, and the Shortcomings of Private International Law
}

\author{
GRALF-PETER CALLIESS* \& JENS MERTENS**
}

\begin{abstract}
In this article we criticize the so-called more economic approach to European competition law for disregarding the importance of a functional system of private law. Based on the availability of market governance as an alternative mode for organizing transactions, it is presumed that vertical integration, which is the central organizational structure of transnational corporations, is economically efficient. Since the enforcement of cross-border contracts by state-organized systems of private law, however, is insufficient, "make-or-buy" decisions in international commerce are prejudiced against arms' length transactions in markets. Consequently, international transactions are integrated vertically into firms' structures to a higher degree than comparable domestic transactions organized in the shadow of domestic private law. The resulting overintegration of world markets leads to reduced competitive incentives and high bureaucratic costs. Contrary to the fundamental assumptions of the more economic approach, vertical integration does not, therefore, foster consumer welfare in the global economy per se. However, as this overintegration is a reasonable reaction to the deficits in state protection of cross-border contracts, a strict world antitrust law cannot counter it without suppressing cross-border exchange. Thus, international private law policy establishing legal certainty in the enforcement of cross-border contracts currently seems to be the instrument of choice in promoting competition in the global economy.
\end{abstract}

* Dr. Gralf-Peter Calliess is Professor for Private Law and International Commercial Law at the law department of the University of Bremen. He is head of the research project "Legal Certainty and Fairness in Global Exchange Processes" at the Collaborative Research Center 597 "Transformations of the State." More information at www.handelsrecht.unibremen.de.

** Jens Mertens is a research associate and finished his $\mathrm{PhD}$ in law at the University of Bremen in 2011 with the research project "Legal Certainty and Fairness in Global Exchange Processes" at the Collaborative Research Center 597 "Transformations of the State."

Indiana Journal of Global Legal Studies Vol. 18 \#2 (Summer 2011)

(C) Indiana University Maurer School of Law 


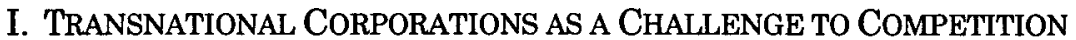 POLICY}

The fundamental nexus of private law and competition policy is mundane: economic competition requires a functional market, which in turn requires effective institutions for the enforcement of contracts. ${ }^{1}$ The economic constitution in an ordoliberal sense, therefore, consists not only of a regulatory part, which aims at protecting competition against state restrictions (fundamental freedoms) and private limitations (antitrust law) alike, but it also entails a facilitative part, which aims at protecting individuals against the opportunistic behavior of their transaction partners (through private rights and remedies). ${ }^{2}$ According to institutional economist and Nobel laureate Douglass C. North, the latter is so essential that the economic problems of many developing and transition countries can be explained by respective deficiencies in their domestic legal systems. ${ }^{3}$ However, institutions for the enforcement of contracts are not only provided by the state but also via private self-organization. ${ }^{4}$ The rise of European trade at the end of the Middle Ages was, for instance, based on institutions created by merchants themselves. ${ }^{5}$ It was not until the nineteenth century that commercial law became nationalized in Europe; thereby nation-states established the institutional foundation for their economic rise. ${ }^{6}$ Since then, the existence of an effective system of private rights and remedies organized by the state has been seen as a matter of course, which is why the market-constitutive function of private law

1. Detailed in Gillian K. Hadfield, The Many Legal Institutions that Support Contractual Commitments, in HANDBOOK OF NEW INSTITUTIONAL ECONOMICS 175 (Claude Ménard \& Mary M. Shirley eds., 2008).

2. See Wolfgang Kerber \& Viktor Vanberg, Constitutional Aspects of Party Autonomy and Its Limits - The Perspective of Constitutional Economics, in PARTY AUTONOMY AND THE ROLE OF INFORMATION IN THE INTERNAL MARKET 49 (Stefan Grundmann et al. eds., 2001) (citing JaMEs M. Buchanan, THE LIMITS OF LIBERTY: BETWEEN ANARCHY AND LEVIATHAN (1975)); Franz Böhm, Privatrechtsgesellschaft und Marktwirtschaft, 17 JAHRBUCH FÜR DIE ORDNUNG VON WIRTSCHAFT UND GESELLSCHAFT [ORDO] 75 (1966).

3. See Douglass C. NoRTh, Institutions, Institutional Change and Economic PERFORMANCE 59-60 (1990); cf. THRÁINN EgGERTSSON, IMPERFECT INSTTTUTIONS: POSSIBILITIES AND LIMITS OF REFORM 82 (2005).

4. For more detail, see AVINASH K. DIXIT, LAWLESSNESS AND ECONOMICS: ALternative MODES OF GOVERNANCE 97-110 (2004).

5. See generally AVNer GReIF, Institutions and the PATH to the Modern Economy: LESSONS FROM MEDIEVAL TRADE 55-152 (2006).

6. Gralf-Peter Calliess, The Making of Transnational Contract Law, 14 IND. J. GLoBAL LEGAL STUD. 469, 473-74 (2007). 
hardly finds any attention in the current debate about competition policy and antitrust legislation on a global level. ${ }^{7}$

However, the neglect of the private law foundations of competition becomes problematic when established institutions meant to enforce contracts become less and less effective. ${ }^{8}$ Yet, this is precisely what is currently happening, insofar as law seems to be unable to keep pace with the globalization of the economy. National private law provides legal certainty, namely for the domestic market, while cross-border exchange is filled with numerous uncertainties regarding the enforcement of contracts. ${ }^{9}$ Those uncertainties result in additional transaction costs, which have a trade-restricting effect equivalent to customs duties. ${ }^{10}$ Empirical studies confirm that the parties to cross-border transactions only rely on state-organized private law to a marginal extent; instead, global trade relies on numerous forms of private governance, from relational contracts and reputational networks to means of arbitration. ${ }^{11}$

From the vista of competition policy, vertical integration is of particular significance in overcoming the constitutional uncertainty ${ }^{12}$

7. See, e.g., OLIVER Budzinski, The Governance of Global Competition (2008) (suggesting that intermediate position on how governance of global competition should occur, between the extremes of completely decentralized firm-imposed governance and completely centralized global laws); MAHER M. DABBAH, THE INTERNATIONALISATTON OF ANTTTRUST POLICY (2003) (describing the nature of the "internationalization process," and analyzing whether it is a matter of law or politics and making suggestions about the development of the process); Hans-Jürgen Ruppelt, Competition Policy in an Interdependent World Economy, in COMPETTTION POLICY IN AN INTERDEPENDENT WORLD ECONOMY (Erhard Kantzenbach et al. eds., 1993).

8. DIXIT, supra note 4 , at 3 "Thus conventional economic theory does not underestimate the importance of law; rather, the problem is that it takes the existence of a well-functioning institution of state law for granted."). This applies similarly for the legal debate.

9. See Christian Bühring-Uhle ET AL., ARBitration and MEdiation in INTERNATIONAL BUSINESS 12-27 ( $2 \mathrm{~d}$ ed. 2006).

10. See James E. Anderson \& Eric van Wincoop, Trade Costs, 42 J. ECON. LITERATURE 691, 721-23 (2004) (containing a literature survey with further references).

11. Gralf-Peter Calliess et al., Transformations of Commercial Law: New Forms of Legal Certainty for Globalized Exchange Processes?, in TRANSFORMING THE GOLDEN-AGE NATTON STATE (Achim Hurrelmann et al. eds., 2007); Thomas Dietz \& Holger Nieswandt, The Emergence of Transnational Cooperation in the Software Industry, in CONTRACTUAL CerTaINTY IN INTERNATIONAL TRADE: EMPIRICAL STUDIES AND THEORETICAL Debates ON INSTITUTIONAL SUPPORT FOR GLOBAL ECONOMIC EXCHANGES 87 (Volkmar Gessner ed., 2009) [collection hereinafter CONTRACTUAL CERTAINTY]; Wioletta Konradi, The Role of Lex Mercatoria in Supporting Globalised Transactions: An Empirical Insight into the Governance Structure of the Timber Industry, in CONTRACTUAL CERTAINTY, supra, at 49; Fabian P. Sosa, Cross-Border Dispute Resolution from the Perspective of Mid-Sized Law Firms: The Example of International Commercial Arbitration, in CONTRACTUAL CERTAINTY, supra, at 107.

12. Cf. Dieter Schmidtchen \& Hans Jörg Schmidt-Trenz, New Institutional Economics of International Transactions: Constitutional Uncertainty and the Creation of Institutions in Foreign Trade as Exemplified by the Multinational Firm, 9 JAHRBUCH FŬR NEUE POLITISCHE 
inherent in cross-border transactions. Instead of importing preproducts via foreign suppliers from the world market and selling them as assembled products to foreign merchants, an internationally active corporation can alternatively create these processes through foreign subsidiaries. Transaction cost economics inquires into the conditions of these so-called make-or-buy decisions. In the given context, it is decisive that vertical integration excludes cross-border transactions from the market. Therefore, a functional system of private law is not required in terms of contract enforcement, as there are no independent parties involved in the transaction. In the case of intrafirm trade, cooperation problems can be solved within the corporate hierarchy by means of fiat.13

Transnational corporations and their network of suppliers and distributors hold great significance for world trade. ${ }^{14}$ The classic transnational corporation consists of a parent company that controls foreign subsidiaries through equity shares safeguarded by national property law and company law. ${ }^{15}$ The parent company therefore provides foreign direct investments: it acquires a controlling interest in foreign sites and facilities or establishes subsidiaries, thereby safeguarding a substantial influence on company policy. ${ }^{16}$ The importance of transnational corporations becomes obvious when looking at the recent growth of global foreign direct investments; they rose from about $\$ 200$ billion in 1989 to a record high of $\$ 1,833$ billion in 2007 , of which crossborder mergers accounted for a significant part. ${ }^{17}$

There is no reliable data available on transnational corporations' share of global exports. Yet, since the mid-1980s, foreign direct investments have grown more rapidly than world exports and the world economy as such. ${ }^{18}$ According to estimates by the United Nations

ÖKONOMIE 3, 18-19 (1990) (explaining that constitutional uncertainty results from the "possessive security" of protective states and the "absence of transactional security" in foreign trade).

13. Oliver E. Williamson, The Economics of Governance, 95 AM. ECON. REv. 1, 7 (2005); see also GIORGIO BARBA NAVARETTI \& ANTHONY J. VENABLES, MULTINATIONAL FiRMS IN THE WORLD ECONOMY 99-126 (2004) (concerning multinational corporations in particular).

14. See John H. Dunning \& Sarianna M. Lundan, Multinational EnTERPRises and THE GLOBAL ECONOMY 463-502 (2d ed. 2008).

15. See Peter T. Muchlinski, Multinational Enterprises and the LaW 56 (2d ed. 2007).

16. Bruce A. Blonigen, Foreign Direct Investment, in THE New PALGRAVE DictionaRY OF ECONOMICS (Steven N. Durlauf \& Lawrence E. Blume eds., 2008), available at http://www.dictionaryofeconomics.com/article?id=pde2008_F000168.

17. U.N. Conference on Trade \& Dev. [UNCTAD], World Investment Report 2008: Transnational Corporations and the Infrastructure Challenge, at 3, U.N. Sales No. E.08.II.D.23 (2008), available at http://www.unctad.org/en/docs/wir2008_en.pdf.

18. See DUNNING \& LUNDAN, supra note 14, at 17-20 (discussing also the limited reliability of the data); cf. Pol Antràs, Firms, Contracts, And Trade Structure, 118 Q.J. ECON. 
Conference on Trade and Development, intrafirm trade within transnational corporations accounts for one-third of world exports, and this share is even larger if one includes the nonequity relationships of transnational corporations with companies in their supply or distribution chain, which the former de facto control due to existing economic dependency (e.g., international subcontracting, licensing, contract manufacturers). ${ }^{19}$

This fact-that is, the central thesis of this article-questions a number of fundamental assumptions of current competition policy. In the following, we illustrate this point with regard to the assessment of vertical integration in antitrust regulation. Anticompetitive agreements, as well as mergers in the vertical dimension (i.e., between enterprises operating at different levels of the supply chain), are subject to regulation by European competition law. From the view of transaction cost economics, however, vertical integration leads to increased efficiency, the advantages of which are ultimately passed on to consumers. This is why antitrust authorities are suggested to scrutinize vertical agreements and vertical mergers in a rather lax manner. ${ }^{20}$ This economic view of antitrust law has recently also found its way into European competition policy as the so-called more economic approach. ${ }^{21}$

The fact that transaction cost theory provides no verifiable criteria that would allow antitrust authorities to distinguish between efficient and inefficient forms of vertical integration is especially problematic. In this regard, one relies on the mere assumption of efficiency, as from an evolutionary perspective, an inefficient level of vertical integration would not survive at the market. Accordingly, oversized firms cannot keep up with smaller competitors due to overwhelming bureaucratic costs. The former either react by outsourcing noncore competences to third parties or they vanish from the market. ${ }^{22}$ However, this exact assumption loses its

1375 (2003) (describing and analyzing systematic patterns in the development of world intrafirm trade volume, using data from U.S. firms).

19. UNCTAD, WORLD INVESTMENT REPORT 2002: TRANSNATIONAL CORPORATIONS AND EXPORT COMPETITIVENESS, at 1, U.N. Doc. UNCTAD/WIR/2002 (2002), available at http://www.unctad.org/en/docs/wir2002overview_en.pdf.

20. For more information, see the seminal work by OLIVER E. WILLIAMSON, MARKETS AND HIERARCHIES, ANALYSIS AND ANTTTRUST IMPLICATIONS (1975), in which he combines economics and organization theory.

21. See, e.g., THE MORE ECONOMT APPROACH TO EUROPEAN COMPETTTON LAW (Dieter Schmidtchen et al. eds., 2007).

22. Williamson, supra note 13 , at 12 ('TT]ry markets, try hybrids, and have recourse to the firm only when all else fails."). For the theoretical problems of taking efficiency criteria into account as normative goals of competition policy, see Wolfgang Kerber, Should Competition Law Promote Efficiency? Some Reflections of an Economist on the Normative Foundations of Competition Law, in ECONOMIC THEORY AND COMPETTTION LAW (Josef Drexl 
foundation once the state does not provide the institutional preconditions for market exchange, as is the case at the global level. In the face of the above-outlined legal uncertainty in the enforcement of cross-border contracts, transactions that domestically could easily take place in the market are instead converted into the organizational forms of hybrids or hierarchy on the international level. ${ }^{23}$ The following theses therefore deserve closer inspection:

1. Concerning the enforcement of cross-border contracts, the protection afforded by state-organized systems of private law is inadequate. As a result, international transactions are integrated vertically to a higher degree than is economically sensible for comparable domestic transactions.

2. This overintegration of world markets leads to reduced competitive incentives and high bureaucratic costs. Contrary to the fundamental assumptions of the "more economic approach," vertical integration does not foster consumer welfare per se. Rather, it can prove to be an economically inefficient reaction to the deficit in state protection of crossborder contracts.

3. However, the excess of cross-border vertical integration cannot be countered by a strict world antitrust law, but only by establishing legal certainty in the enforcement of cross-border contracts. In this sense, private law policy is currently the best global competition policy.

In order to elaborate these theses further, in part II, we first introduce the model of the firm as the functional equivalent of the market, and in part III, we apply the model to the different legal organizational forms of transnational corporations. With the help of this theoretical concept, we will then demonstrate why the general support of vertical integration by proponents of the more economic approach (see part IV) is out of place when it comes to cross-border transactions (see part V). In part VI, our conclusion, we postulate to pursue competition policy through the provision of effective legal protection of cross-border transactions by means of private law.

et al. eds., 2009), available at http://www.uni-marburg.de/fb02/makro/forschung/gelbereihe/ artikel/2007-09_kerber.pdf.

23. Rebecca Hellerstein \& Sofia B. Villas-Boas, Outsourcing and Pass-Through 24 (Univ. of Cal, Berkeley, Dep't of Agric. \& Res. Econ. \& Policy, CUDARE Working Paper No. 1016R3, Feb. 26, 2009), available at http://repositories.cdlib.org/cgi/viewcontent. cgi?article $=1112$ \&context=are_ucb. 


\section{CROSS-BORDER TRANSACTIONS: TO MAKE OR BUY INTERNATIONALLY}

The business decision to organize cross-border transactions in the form of intrafirm trade within a transnational corporation is so complex that the respective literature offers numerous explanatory approaches. ${ }^{24}$ Hymer originally rooted the comparative advantage of transnational corporations vis-à-vis domestic competitors in their extended monopolistic positions. ${ }^{25}$ Modern business organization literature focuses on the specific knowledge-based advantages of corporate structures. ${ }^{26}$ The outline below follows Dunning's "eclectic paradigm," which systematically combines different advantages of a corporation in a broad theoretical framework. ${ }^{27}$

\section{A. Ownership-and Location-Advantages of the Firm}

The pooling of processes within a firm leading to cost and competitive advantages is very important. For instance, investments in a strong brand name or in the development of plans and patents are capital intensive, but they can be transferred to subsidiaries without much additional costs. Similarly, the joint conduct of corporate management and administration can lead to economies of scale. Economies of scope can, for instance, emerge through a bundled purchasing policy, when it comes to the production of complementary products. Furthermore, transnational corporations also provide advantages of location through the flexible intrafirm relocation of production to different nation-states. This strategy allows these corporations to capitalize on advantages in labor costs and taxes and reduce the risk of currency fluctuations.

24. For an overview, see Jean-François Hennart, Theories of the Multinational Enterprise, in THE OXFORD HANDBOOK OF INTERNATIONAL Business (Alan M. Rugman ed., 2009).

25. See Stephen H. Hymer, The International Operations of National Firms (2d ed. 1976).

26. See Anil K. Gupta \& Vijay Govindarajan, Knowledge Flows Within Multinational Corporations, 21 STRATEGIC MGMT. J. 473, 473-74 (2000); Bruce Kogut \& Udo Zander, Knowledge of the Firm and the Evolutionary Theory of the Multinational Corporation, 24 J. INT'L BUS. STUD. 625, 625-27 (1993).

27. DUNNING \& LUNDAN, supra note 14, at 95 (using the terms "ownership-," "location-," and "internalization-advantages"). Another overview can be found in James R. Markusen, The Boundaries of Multinational Enterprises and the Theory of International Trade, $9 \mathrm{~J}$. ECON. PERSP. 169 (1995). 


\section{B. Internalization Advantages: The Firm as Functional Equivalent of the Market}

However, on their own, these outlined advantages often do not sufficiently explain why the expansion of one's organizational structure into foreign countries is ultimately beneficial. Many of these advantages could be realized by just licensing an independent company, thereby avoiding the high costs of establishing a foreign subsidiary. For instance, low wage costs do not provide a convincing reason for integrating a production process into a corporation, as a company can similarly benefit from them both by purchasing (pre-)products from an independent supplier according to local wage costs and prices, or by licensing a foreign enterprise to produce and sell end products locally. High costs for research and development could similarly be financed by licensing agreements with other enterprises.

Therefore, there must be another specific advantage offered by transnational corporations that importing or licensing cannot provide. ${ }^{28}$ One other important feature of the corporate structure is that it generates the institutional preconditions for the conduct of cross-border transactions internally. By organizing transactions within the corporate structure as a functional equivalent of the free market, problems with external transaction partners can be avoided. ${ }^{29}$ Conflict resolution mechanisms are made available by structures of dependency and hierarchy. Due to its connection to the central thesis of this article, the advantage of internalization is further detailed in the following sections and provides the backdrop for the subsequent argument. This is not to say that internalization is a sufficient or unique explanatory approach to crossborder vertical integration. Rather, we recognize that internalization theory hints at one reason among others for the existence of firms. However, we argue that-all other circumstances being equal-the lack of facilitative private law for cross-border transactions does provide an explanation for the level of vertical integration of transactions, which is often underestimated.

\section{The Essential Features of Transaction Cost Theory}

The notion that the formation of companies is a reaction to the high costs of the market mechanism is a decisive one. Established in 1937 by

28. Markusen, supra note 27, at 181

29. Alan M. Rugman, InSDE the Multinationals: The Economics of Internal MARKETS 4 (1981). 
Coase, and further refined by Williamson, ${ }^{30}$ this approach starts with the assumption that every transaction necessarily produces frictional losses, not caused by the costs of production, materials, personnel, or transport, but by interpersonal communication and interaction at economic interfaces: the so-called transaction costs. ${ }^{31}$ The level of transaction costs is influenced by three factors: specificity, uncertainty, and the frequency of transactions. ${ }^{32}$

Specificity denotes the extent of certain expenditures for a particular transaction-such as investments in material, personnel, or development-that cannot be transferred to a different transaction context (sunk costs). For instance, if an automotive supplier opens an assembly line that can only produce parts for a particular vehicle manufacturer, this is a highly specific transaction, as the investment of the supplier can only pay off through a successful exchange with this particular manufacturer. Conversely, unspecific assets would be, for example, the one-time purchase of some raw material, as the parties could also use their right of disposal in other transaction contexts without loss.

Uncertainty refers to the behavior of parties that are assumed to act opportunistically. The common advantage stemming from the conduct of transactions according to agreement becomes threatened when a party aspires to achieve an even higher individual profit through noncooperative behavior. ${ }^{33}$ The parties try to maximize their benefit ex ante through the design of agreements, making costly negotiations necessary. Ex post, the breach of contract looms, thereby causing costs from litigation and the enforcement of law.

Frequency refers to the repetition of individual but uniform transactions between parties. Hence, it is not economically sensible to change one's power supplier daily, because the cost of the change outweighs the potentially achievable gains from lower electricity rates. Uniform exchange occurs frequently, thus becoming embedded in a longterm business relationship or even integrated into a corporate structure.

\section{A Question of Organization: Make or Buy?}

Transaction cost theory analyzes individual transactions at the microlevel. It is crucial that a transaction signifies the transfer of a good or

30. See R.H. Coase, The Nature of the Firm, 4 ECONOMICA, NEW SERIES 386 (1937); Oliver E. Williamson, Transaction-Cost Economics: The Governance of Contractual Relations, 22 J.L. \& ECON. 233 (1979).

31. Oliver E. Williamson, The Economic Institutions of CAPITALism 18-23 (1985) ('Transaction costs are the economic equivalent of friction in physical systems.').

32. Id. at $52-61$.

33. Id. at 34 . 
service via a technologically separable interface-which does not necessarily comprise a crossing of legal boundaries between separate legal entities. As the conduct of transactions can be arranged in a variety of different institutional arrangements, it is a central matter as to which institutional design produces the lowest transaction costs. Three different modes of governance are available.

First, market governance signifies one extreme in the continuum of organizational forms; it allows independent parties to meet without having to establish or maintain relations beyond an individual business transaction (arm's length trade) ${ }^{34}$ From a legal perspective, it represents the conclusion of individual contracts of sale or for services between independent legal subjects, encompassing all aspects of the transaction once and for all. While the interplay of independent parties at the market produces low bureaucratic costs and a high level of competition for simple transactions, these instruments are far more problematic when it comes to complex transactions. As all future developments have to be comprehensively taken into account, transaction costs increase dramatically through complex contract negotiations and a lack of flexibility. Additionally, specific investments increase the dependency on the goodwill of the business partner, who can take advantage of the situation by breaching the contract or by using blackmailing techniques in renegotiations.

Second, in order to counter this so-called hold-up problematique, different bilateral and trilateral governance mechanisms are available in the hybrid governance mode. ${ }^{35}$ Their fundamental feature is to provide positive incentives for the performance of a contract through the prospect of continued transactions and good reputation in long-term, personal, dependent relations. ${ }^{36}$ Bilateral relational contracts ${ }^{37}$ do not have to determine all details in advance; rather, they can remain flexible due to long-term interdependencies. Trilateral forms of organizations are, for

34. Id. at 73; Ian R. MacNeil, Contracts: Adjustment of Long-Term Economic Relations Under Classical, Neoclassical, and Relational Contract Law, 72 Nw. U. L. REV. 854, 856-59 (1977).

35. See WILLIAMSON, supra note 31 , at 249.

36. See Hans-Jörg Schmidt-Trenz \& Dieter Schmidtchen, Private International Trade in the Shadow of the Territoriality of Law: Why Does It Work?, 58 S. ECON. J. 329, 332-36 (1991) (describing the incentives for repeated transactions).

37. See MacNeil, supra note 34, at 889-94; Ian R. MacNeil, Relational Contract: What We Do and Do Not Know, 1985 WIS. L. REV. 483 (describing the relational nature of contracts); Stewart MacAulay, Non-Contractual Relations in Business: A Preliminary Study, 28 AM. Soc. REv. 55 (1963) (presenting a study describing how businessmen often leave out defining a contractual relationship completely and often avoid resort to legal sanction). 
instance, reputation-based trading networks or the involvement of arbitrators, intermediaries, and banks respectively. ${ }^{38}$

Third, in order to avoid the uncertainty of market transactions entirely, transactions can also take place within a unitary corporate structure (i.e., within the firm as an organizational antipode to the market (the uniform governance mode)). In this case, the business units do not conclude contracts of sale or service among each other, as de jure, they are part of the same legal entity that cannot enter into a contract with itself. Rather, the corporate management controls transactions hierarchically.

The different organizational forms can be pictured schematically as follows:

Figure 1: The Make-or-Buy Decision and the Organizational Variants of Transactions $^{39}$

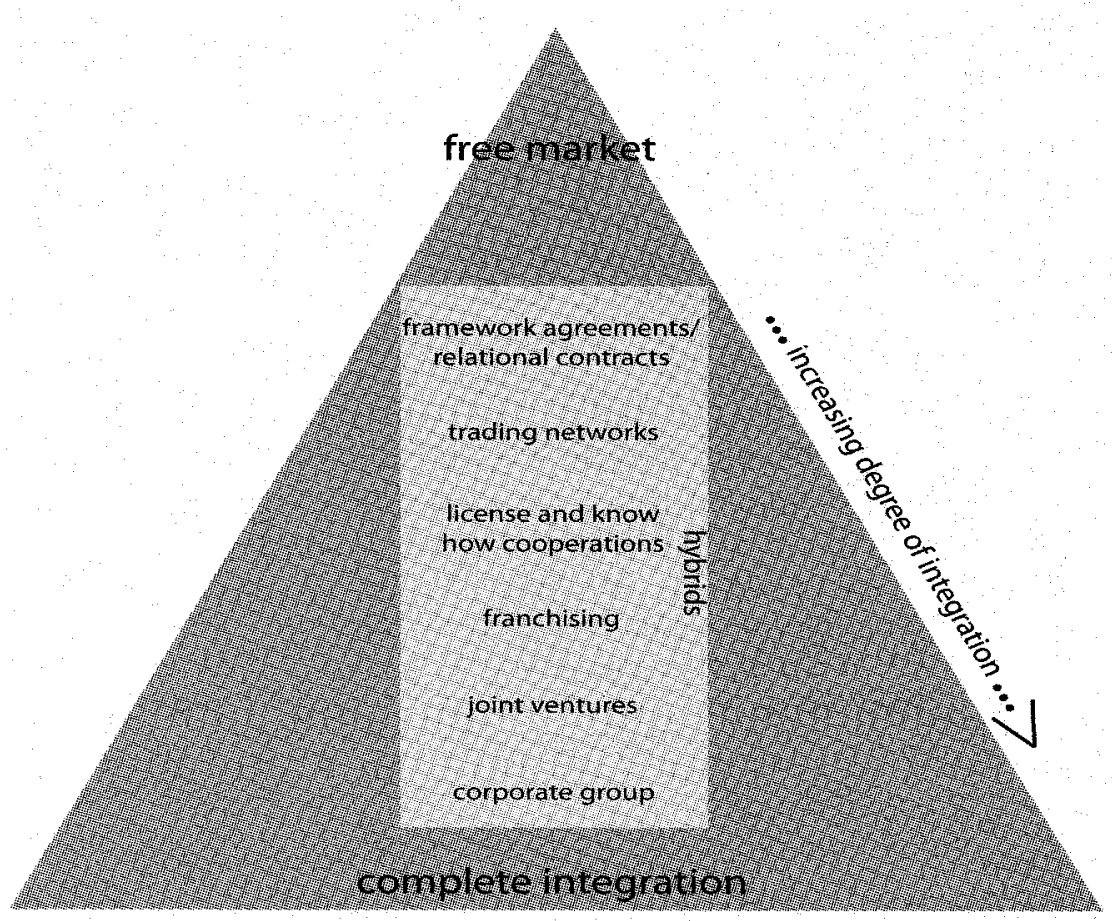

38. See Gralf-Peter Calliess, Transnational Civil Regimes: Economic Globalization and the Evolution of Commercial Law, in CONTRACTUAL CERTAINTY, supra note 11, at 215.

39. Source: 'The authors' own design, following Arnold Picot, Ein neuer Ansatz zur Gestaltung von Leistungstiefe, SCHMALENBACHS ZEITSCHRIFT FÜR BETRIEBSWIRTSCHAFTLICHE FORSCHUNG 1991, at 336, 340. 


\section{The CONTROL OF TRANSACTIONS IN DifFERENT TYPES OF TRANSNATIONAL CORPORATIONS}

At this point, it is significant how these organizational models in theoretical accounts are reflected in different types of transnational corporations.

If a parent company owns all the shares of a foreign subsidiary, from an economic viewpoint, the corporate structure equals the model of a hierarchical firm in transaction cost theory. Even if subsidiaries are mostly constituted as independent legal entities according to the rules and regulations of their respective home countries, internal firm conflicts can be resolved either by the corporate structure, the shareholder authority under company law, or internal mediation mechanisms. Usually authority is exercised by (threat of) intervention into personnel policy, whereby factually binding instructions are given to the management of the subsidiary. Thus, the firm becomes its own "court of ultimate appeal." 40

As hierarchical structures become relatively inflexible with the growing size of a corporation, increasingly flatter "heterarchical" structures are implemented, linking individual units of a corporation in a network-like fashion, without making integration into the parent company by means of shareholder control a mandatory step. ${ }^{41}$ Thus, without the means of majority shareholder influence, classic hierarchical structures are often unavailable for the resolution of conflicts. ${ }^{42}$ If the share ratio does not allow direct instructions, influence can often only be exerted indirectly via participation in individual questions or personnel decisions through minority voting rights. If no equity involvement exists at all, the distinction from hybrid forms of organization becomes blurred. The loose links in such network corporations, which are no longer corporate entities in the classical sense, are based on relational contracts. In order to achieve stable expectations for network-internal transactions, these contracts draw on

40. Williamson, supra note 13 , at 9-10.

41. MUCHLINSKI, supra note 15 at $57-61$; see also UNCTAD, supra note 17 , at 249 ("Foreign direct investors may also obtain an effective voice in the management of another business entity through means other than acquiring an equity stake. These are also nonequity forms of investment, which include, among other things, subcontracting, management contracts, turnkey arrangements, franchising, licensing and product-sharing.").

42. According to German law, for instance, contracts of domination under Section 293 I AktG require the consent of at least $75 \%$ of votes present at a decision. Aktiengesetz [AktG] [Stock Corporation Act], Sept. 6, 1965, BUNDESGESETZBLATT [BGBl. I] at 1089, last amended by Gesetz [G], Dec. 9, 2010, BGBl. I at 1900, § 293 (Ger.). 
the incentive for repeated exchange and reputational mechanisms. ${ }^{43}$ Based on continued business transactions, joint ventures are ultimately long-term framework contracts, in which two or more companies work together without one party controlling another hierarchically. MacNeil even argues that "the corporation itself is one of the greatest relational contracts ever." 44

The classic criteria according to which a parent company has to be able to control its subsidiaries by virtue of equity shares does not do complete justice to modern forms of corporations. New approaches in defining transnational corporations are therefore often very general, such as the Organization for Economic Cooperation and Development's "Guidelines on Multinational Enterprises":

[Multinational enterprises] usually comprise companies or other entities established in more than one country and so linked that they may co-ordinate their operations in various ways. While one or more of these entities may be able to exercise a significant influence over the activities of others, their degree of autonomy within the enterprise may vary widely from one multinational enterprise to another. ${ }^{45}$

Accordingly, the essential feature here is the ability of one or several corporate units to control the others, regardless of whether their links are arranged by means of equity shares or contract only. The vagueness of this definition causes numerous problems, such as the issue of responsibility and liability of corporate units for the misconduct of business units linked only by so-called control contracts. ${ }^{46}$ For the purpose of this article, however, such a broad definition illustrates that transnational corporations are not congruent with the Williamsonian firm as a unilateral hierarchical apparatus. Rather, they have a broad range of instruments at their disposal to generate sufficiently stable expectations for transactions through self-organized institutions. Besides classic hierarchy, increasingly, hybrid governance mechanisms-in the form of dependency relations established by

43. See Walter W. Powell, Neither Market nor Hierarchy: Network Forms of Organization, 12 RES. ORG. BEHAV. 295, 303-05 (1990); Schmidtchen \& Schmidt-Trenz, supra note 12, at 22-26.

44. MacNeil, supra note 37 , at 492.

45. ORG. FOR ECON. COOPERATION \& DEv. [OECD], OECD GUIDELINES FOR MULTINATIONAL ENTERPRISES 12 (2008), available at http://www.oecd.org/dataoecd 56/36/1922428.pdf.

46. See MUCHIINSKI, supra note 15 , at 78. 
relational contracts-are used to safeguard transactions within the corporate structure.

\section{AN EVALUATION OF TRANSNATIONAL CORPORATIONS REGARDING COMPETITION POLICY}

As noted above, transnational corporations are important for the organization of cross-border trade. However, their economic power raises concerns as to competition policy. In the following section, we address in what way transnational corporations affect cross-border trade and how this is perceived in competition policy.

\section{A. Transnational Corporations as a Form of Vertical Integration}

To what extent is the insight that transnational corporations, as a functional equivalent of market governance, integrate transactions into structures of hierarchy and dependency significant for their assessment in competition policy? This functional conception allows one to draw conclusions about those economic relations typically affected. Two corporations operating at the same level of the supply chain normally do not exchange goods and services, as they are not complementary. Horizontal integration can occur if the whole production process is taken over by foreign subsidiaries, or if research and development cooperations exist. However, the make-or-buy decision is especially required when it comes to transactions between market participants operating at different levels of the supply chain, for instance, when raw materials or supplier parts are acquired or when end products are sold. Thus, as far as control is achieved by means of equity involvement, vertical mergers are primarily relevant for competition policy. At the European level, these mergers are regulated by the European Competition (EC) merger regulation. However, in modern heterarchical concepts of corporations that are governed by relational contracts, vertical agreements regulated by Article 101(1) of the Treaty on the Functioning of the European Union (TFEU) (formerly Article 81(3) of the Treaty on the European Union) are significant. ${ }^{47}$ In the following, the term "vertical integration" is used as a broad concept covering all facets of the integration of transactions into corporate structures or structures of dependency.

47. Consolidated Version of the Treaty on the Functioning of the European Union art. 101(1), Sept. 5, 2008, 2008 O.J. (C 115) 88 [hereinafter TFEU], available at http://eurlex.europa.eu/LexUriServ/LexUriServ.do?uri=0J:C:2008:115:0047:0199:EN:PDF. 
Before the next section details substantial aspects in the assessment of vertical integration in cross-border markets, it is first helpful to recall the numerous controversies in the history of the treatment of vertical integration in the most important economic jurisdictions-the United States and European Union. 48

\section{B. The U.S. School: From Harvard to Chicago}

After an initial orientation phase and the introduction of national competition law through the Sherman Act of 1890, the dominant opinion at the beginning of the twentieth century in the United States was that vertical integration would typically hamper competition by allowing companies to gain market power and harm competitors. Grown out of the economic thinking of the Harvard school, this utterly restrictive basic attitude toward all forms of vertical mergers and agreements shaped U.S. competition theory and practice into the 1970s. Due to fundamental criticism of lawyers and economists close to the Chicago school, ${ }^{49}$ since the beginning of the 1980s an extremely liberal attitude toward vertical mergers and agreements dominated practice so that such measures remained almost entirely without objections from then on. ${ }^{50}$

Chicago reproached the Harvard school for developing a phobia about market power, which had no basis in economic theory and prevented a potential increase of efficiency gained through sensible forms of vertical integration. However, the Chicago school itself applied a strictly rational model based on neoclassical pricing theory, arguing that vertical integration could not be a consequence of the desire for market-dominant positions. First, as the ideal monopoly rent can be achieved by dominating only one economic stage, there is no incentive for the expansion of a market-dominant position from one economic stage to another. Second, it would be no advantage to invest resources in superseding competitors, as principally, no restrictions to market

48. See generally JEFFrEY CHURCH, THE IMPACT OF VERTICAL AND CONGLOMERATE MERGERS ON COMPETITION (2004), available at http://ec.europa.eu/competition/mergers/ studies_reports/merger_impact.pdf (providing more details on antitrust concerns in relation to vertical mergers, in a final report to the European Commission); Michael H. Riordan \& Steven C. Salop, Evaluating Vertical Mergers: A Post-Chicago Approach, 63 ANTTTRUST L.J. 513 (1995) (describing the lack of consensus about when anticompetitive effects can occur in the area of vertical price agreements).

49. See, e.g., Robert Bork, The antitrust Paradox: A Policy at War With Itself (1978); Richard Posner, The Chicago School of Antitrust Analysis, 127 U. PA. L. REv. 925 (1979) (describing the seminal criticisms of lawyers and economists belonging to the Chicago school of thought).

50. Massimo MotTa, Competition Policy: Theory and Practice 8-9 (2004). 
access exist and hence, new competitors would enter the market. This assumption allowed the argument that vertical integration was not motivated by a desire for market power but was instead concerned with efficiency advantages, ${ }^{51}$ which from the perspective of transaction cost theory could be achieved by moving exchange processes from the unassisted market into corporate organizations. ${ }^{52}$ In terms of antitrust, vertical integration was harmless, or even desirable, ${ }^{53}$ as it served consumer welfare as the sole aim of competition policy. ${ }^{54}$

\section{The Current Assessment in European Competition Law}

Even if the theoretical foundations of competition policy today are significantly more complex than at the time of the advent of the Chicago school, efficiency criteria are still fundamentally influential and have gained significance in practice and the literature on this side of the Atlantic as well. 55 This development is manifest in the competition law of the European Union, which has gradually become economized in the course of the so-called more economic approach. ${ }^{56}$ The relevant

51. Posner, supra note 49 , at 927 . For a similar outline, see MUCHLINSKI, supra note 15 , at 41 .

52. Oliver E. WILLJamson, Transaction Cost Economics, in HandBooK OF NEW InSTITUTIONAL ECONOMiCS 41, 58 (Claude Ménard \& Mary M. Shirley eds., 2005).

53. See Posner, supra note 49, at 929; BoRK, supra note 49, at 226 ("Antitrust's concern with vertical mergers is mistaken. Vertical mergers are means of creating efficiency, not of injuring competition. ... The vertical mergers the law currently outlaws have no effect other than the creation of efficiency."); $i d$. at 297 ("We have seen that vertical price fixing (resale price maintenance), vertical market division (closed dealer territories), and, indeed, all vertical restraints are beneficial to consumers and should for that reason be completely lawful.").

54. For the aims of the Chicago school, see BoRK, supra note 49 , at 81.

55. Margaret Bloom, The Great Reformer: Mario Monti's Legacy in Article 81 and Cartel Policy, COMPETITION POL'Y INT'L, Spring 2005, at 55, 55. Compare the following quote from a speech by Mario Monti, former European Commissioner for Competition Policy: "It is fair to say that the far-reaching policy shift which occurred in US antitrust enforcement during the 1980s - namely, the shift towards a focus on the economic welfare of consumers - has been mirrored in the policy priorities of the European Commission during the 1990's. During my term as Competition Commissioner, I have taken several steps aimed at further reinforcing this trend . . . ." Mario Monti, Eur. Comm'r for Competition Policy, Eur. Comm'n, Address at the UCLA Law First Annual Institute on US and EU Antitrust Aspects of Mergers and Acquisitions: Convergence in EU-US Antitrust Policy Regarding Mergers and Acquisitions: An EU Perspective (Feb. 28, 2004).

56. For more detail, see THE MORE ECONOMIC APPROACH TO EUROPEAN COMPETITION LAW, supra note 21; Damien Geradin, Efficiency Claims in EC Competition Law and SectorSpecific Regulation, in THE EVOLUTION OF EUROPEAN COMPETTTION LAW: WHOSE REgulation, Which COMPETITION? 313 (Hanns Ullrich ed., 2006); Lars-Hendrik Röller, Economic Analysis and Competition Policy Enforcement in Europe, in MoDELLING 
literature, therefore, stresses the advantages of vertical integration, which can lead to lower transaction costs through a better coordination of production, the protection of specific investments against opportunistic behavior, the protection of internal firm know-how, and effective measures against free-riding. ${ }^{57}$ According to the position of the European Commission, as long as sufficient competition exists between the suppliers of comparable products, the restriction of vertical competition is harmless, and even beneficial to competition and efficiency. Concerns exist only in principle if one party acquires market power through a measure or if an existing strong market position is further expanded.58 The gist of the argument refers here mainly to Article 101(3) of the TFEU, which exempts vertical agreements from the ban in Article 101(1) of the TFEU under the premise that consumers have their appropriate share in increased efficiency. ${ }^{59}$ The decree of the block exemption regulations for vertical agreements is evidence of the fundamental assumption that microeconomically efficient forms of vertical integration have such a positive effect that gains in efficiency reach the macroeconomic level through the so-called consumer pass-on.

The notion of efficiency becomes manifest in statutory provisions. Take, for example, recital (6) of the so-called Umbrella Block Exemption of 1999 (vertical block exemption ${ }^{60}$ ), in which the potential decrease of transaction costs through vertical agreements is expressly mentioned. The key role of the efficiency criterion can furthermore be seen in recitals (7) to $(9)^{61}$ as well as in further group exemption regulations geared toward specific economic areas. ${ }^{62}$ The same can be said about the revised version of the European merger regulation, ${ }^{63}$ whose recital (29) states that the assessment of mergers should take account of justified and likely efficiency advantages. In Article 2(1)(b) of the European Community Merger Regulation, the efficiency criterion can be found

European Mergers: Theory, Competition Policy and Case Studies 13 (Peter A.G. van Bergeijk \& Erik Kloosterhuis eds., 2005).

57. E.g., RICHARD WHISH, COMPETITION LAW 616 (6th ed. 2008).

58. See CHURCH, supra note 48 , at 4 .

59. TFEU art. 101(3), Sept. 5, 2008, 2008 O.J. (C 115) 89.

60. Commission Regulation 2790/1999, On the Application of Article 81(3) of the Treaty to Categories of Vertical Agreements and Concerted Practices, recital (6), 1999 O.J. (L 336) $21,21$.

61. Id. at 21 (recitals (7)-(9)).

62. E.g., Commission Regulation 772/2004, On the Application of Article 81(3) of the Treaty to Categories of Technology Transfer Agreements, 2004 O.J. (L 123) 11, 11-12; Commission Regulation 1400/2002, On the Application of Article 81(3) of the Treaty to Categories of Vertical Agreements and Concerted Practices in the Motor Vehicle Sector, 2002 O.J. (L 203) 30, 30.

63. Council Regulation 139/2004, On the Control of Concentrations Between Undertakings (The EC Merger Regulation), recital (29), 2004 O.J. (L 24) 1, 4 (EC). 
again with reference to the development of technological and economic progress. Lastly, the EU Commission has confirmed and concretized this position in its "Guidelines on the Assessment of Non-Horizontal Mergers" 64 by expressly stating that vertical mergers are both basically harmless with regard to competition and generate efficiency gains. ${ }^{65}$

Although it is now acknowledged that vertical agreements and mergers pose issues for competition policy under certain circumstances, the opinion remains dominant that they increase consumers' welfare and should therefore, on principle, not be opposed. ${ }^{66}$

\section{THE BLIND SPOT: CROSS-BORDER VERTICAL INTEGRATION}

The argument for the efficiency advantages of vertical integration rests in the reasoning of transaction cost theory-namely, that dependency structures and corporate structures can compensate for high transaction costs in the market and that this is ultimately positive for consumers and hence, for the economy. It is, however, questionable whether this conclusion can also be drawn for international matters.

\section{A. The Particularity of Cross-Border Transactions}

The transfer of this reasoning on international matters could conflict with a lack of differentiation in the conception of transaction cost theory. Transaction cost theory rests on the implicit assumption that transactions take place against the backdrop of a functioning private law regime organized by the state (i.e., "in the shadow of law"67). But what happens once one leaves the safe terrain of the nation-state?

64. Guidelines on the Assessment of Non-Horizontal Mergers Under the Council Regulation on the Control of Concentrations Between Undertakings, 2008 O.J. (C 265) 6, available at http://ec.europa.eu/comm/competition/mergers/legislation/nonhorizontal guidelines.pdf.

65. The following passages of the guideline support our argument: paragraph 11: "Nonhorizontal mergers are generally less likely to significantly impede effective competition than horizontal mergers."; paragraph 12: "First, unlike horizontal mergers, vertical or conglomerate mergers do not entail the loss of direct competition between the merging firms in the same relevant market. As a result, the main source of anti-competitive effect in horizontal mergers is absent from vertical and conglomerate mergers."; paragraph 13: "Second, vertical and conglomerate mergers provide substantial scope for efficiencies."; and paragraph 14: "Integration may also decrease transaction costs and allow for a better co-ordination in terms of product design, the organisation of the production process, and the way in which the products are sold." Id. at 7 II 11-14.

66. Aluson Jones \& BREnda Sufrin, EC COMpetition LAw: TEXT, CASES, AND MATERIALS 49 (4th ed. 2008).

67. In part, the function of the state legal system in enforcing contracts is emphasized, yet without questioning the existence of the legal system itself. On this point, see RONALD H. 


\section{Constitutional Uncertainty and the International Exchange Dilemma}

At first, it is essential to examine the market-constitutive function of a private law regime. In a primitive exchange situation, in which payment matches delivery and the parties are physically present, additional protective measures seem unnecessary. However, for modern society, which is based on the division of labor, complex transactions that generate goods and services at different locations simultaneously are indispensable. According to game-theoretical parlance, in this case, a so-called prisoner's dilemma arises between entirely isolated transaction partners, ${ }^{68}$ in which uncooperative behavior is, at least for one of the parties, the economically optimal course of action. If no sanctions for a breach of contract exist, both parties have an incentive to act at the expense of the other party. For instance, if a vendor makes an advance delivery of an ordered good, there is no economic incentive for the buyer to come up with the contractually agreed payment in return. If the buyer pays first, there is no incentive for the vendor to deliver the good. As both parties anticipate a breach of contract, no party is willing to perform in advance. ${ }^{69}$

Thus, the exchange of goods and services only takes place if an economic subject can expect with sufficient certainty that an attractive equivalent is acquired for the delivery of a good. Institutions that guarantee legal decisions and enforcement of contracts safeguard this expectation. In order to generate stable expectations between anonymous transaction parties, nation-states established systems of domestic private law that enforced the performance of a contract and the respective claims for damages, even by legitimate force if necessary. ${ }^{70}$ Thereby the prisoner's dilemma is resolved, as the potential costs of a damage award in the case of a breach of contract would exceed the costs for the actual performance of the contract.

However, in the absence of a "world state," there is no supranational world private law regime that would generate-as a functional

COASE, THE FIRM, THE MARKET AND THE LAW 10 (1988), as well as DIXIT, supra note 4, at 3 (Thus conventional economic theory does not underestimate the importance of law; rather, the problem is that it takes the existence of a well-functioning institution of state law for granted.").

68. A game-theoretical argument for this "international exchange dilemma" can, along with other arguments, be found in Schmidt-Trenz \& Schmidtchen, supra note 36, at 331.

69. See DIXIT, supra note 4, at 14; Paul H. Rubin, Legal Systems as Frameworks for Market Exchanges, in HANDBOOK OF NEW INSTITUTIONAL ECONOMICS, supra note 52, at 205, 213.

70. For a description of the state as an independent agent of contract enforcement, see NORTH, supra note 3 , at 58-60. 
equivalent of national private law systems-a level of contractual certainty for cross-border trade comparable to the one provided for transactions within developed nation-states. The judicial settling of conflicts concerning transborder transactions thus always poses three questions: (1) Which nation-states' courts are responsible for resolving the conflict? (2) What national contract laws are the courts supposed to apply in resolving the conflict? (3) Is a judgment from one state recognized and enforceable in another nation-state?71

In theory, these issues are addressed by private international law (PIL). However, contrary to its name, PIL does not represent uniform international law. Rather, every state determines its own conflicts of law provisions. Although the idea for a global private law based on contracts under international law emerged at the end of the nineteenth century, ${ }^{72}$ more than a century of work in different international organizations such as the Hague Conference on Private International Law (since 1893), the International Institute for the Unification of Private Law (UNIDROIT, since 1926), and the United Nations Commission on International Trade Law (since 1966), have only produced piecemeal results, like the U.N. Convention on the International Sale of Goods of $1980 .{ }^{73}$ Hence, the transacting parties are confronted with a plethora of different conflicts of law rules and substantive norms. They cannot rely on the enforcement by state courts because, in contrast to international arbitration, there is still no global agreement about the recognition and enforcement of national judgments. ${ }^{74}$ Whether a foreign law is applied or whether a foreign judgment is actually enforced domestically also depends on how national courts assess the impact on their national ordre public. At least in Europe, these issues have partly been mitigated due to intensive integration efforts. ${ }^{75}$ However, in cross-border transactions with trade

71. Calliess, supra note 6, at 472.

72. See, e.g., Ernst Zitelmann, Die MÖglichkeit eines Weltrechts [The Possibility of a World Law] (1916).

73. For background on the U.N. Convention on the International Sale of Goods (CISG), see generally Franco FERRARI, FONDATION POUR L'ÉTUdE DU DROIT ET DES USAGES DU COMMERCE INTERNATIONAL, QUO VADIS CISG? : CELEBRATING THE 25TH ANNTVERSARY OF THE UNITED NATIONS CONVENTION ON CONTRACTS FOR THE INTERNATIONAL SALE OF GOODS (2005).

74. For background on the Hague Convention on Jurisdiction and Foreign Judgments in Civil and Commercial Matters of 2005, which has still not taken effect, see generally Samuel P. Baumgartner, THe Proposed Hague Convention on JuRISDiction and FOREIGN JUDGMENTS: TRANS-ATLANTIC LAWMAKING FOR TRANSNATIONAL LITIGATION (2003).

75. Especially through Council Regulation 593/2008, On the Law Applicable to Contractual Obligations (Rome I), 2008 O.J. (L 177) 6 (EC); Council Regulation 805/2004, European Enforcement Order for Uncontested Claims, 2004 O.J. (L 143) 15 (EC); Council Regulation 1206/2001, On Cooperation Between the Courts of the Member States in the 
partners outside of Europe, the "constitutional uncertainty"76 often causes such costs that the unassisted market becomes unavailable as a form of organizing cross-border transactions. ${ }^{77}$

\section{The Reactions of Market Participants: Vertical Integration}

International trade therefore relies on numerous private ordering activities that safeguard such transactions institutionally. Relational contracts, trade intermediaries and clubs, letters of credit, arbitration tribunals, and many other related institutions compensate for the constitutional uncertainty that state law leaves in international markets. In this context, it is of central importance that transnational corporations increasingly take measures to safeguard transactions institutionally by their own internal structures (internalization of market processes). ${ }^{78}$ As it is inherent in all private ordering activities that transactions become integrated into bilateral or trilateral dependency structures or structures of hierarchy, in the case of transborder transactions, their organizational form shifts toward vertical integration ceteris paribus (i.e., if the frequency, uncertainty, and specificity of transactions remain unchanged). Graphically, this relation can be illustrated as follows:

Taking of Evidence in Civil or Commercial Matters, 2001 (L 174) 1 (EC); Council Regulation 44/2001, On Jurisdiction and the Recognition and Enforcement of Judgments in Civil and Commercial Matters, 2001 O.J. (L 12) 1 (EC); Eur. Free Trade Ass'n, Convention on Jurisdiction and the Enforcement of Judgments in Civil and Commercial Matters, Sept. 16, 1988, 28 I.L.M. 620; EC Convention on the Law Applicable to Contractual Obligations (Rome 1980), June 19, 1980, 19 I.L.M. 1492.

76. Schmidt-Trenz \& Schmidtchen, supra note 36 , at 331.

77. See Dieter Schmidtchen \& Hans Jörg Schmidt-Trenz, Private Law, The World Production Possibility Frontier and the Need for an International "Private Law Community": German Theory of Order and Constitutional Economies at Work 34 (Univ. of Saarland Ctr. for the Study of New Institutional Econ., Working Paper) ("[T]rades between 'faceless buyers and sellers' . . . hardly work in international trade. They require a developed legal system and protective safeguard which we encounter only in an ideal domestic economy.").

78. See also Calliess, supra note 38 , at 224 . 
Figure 2: The Level of Vertical Integration in Relation to the Specificity of a Transaction, Taking into Account the Availability of State Mechanisms of Private Law for the Protection of Transactions ${ }^{79}$

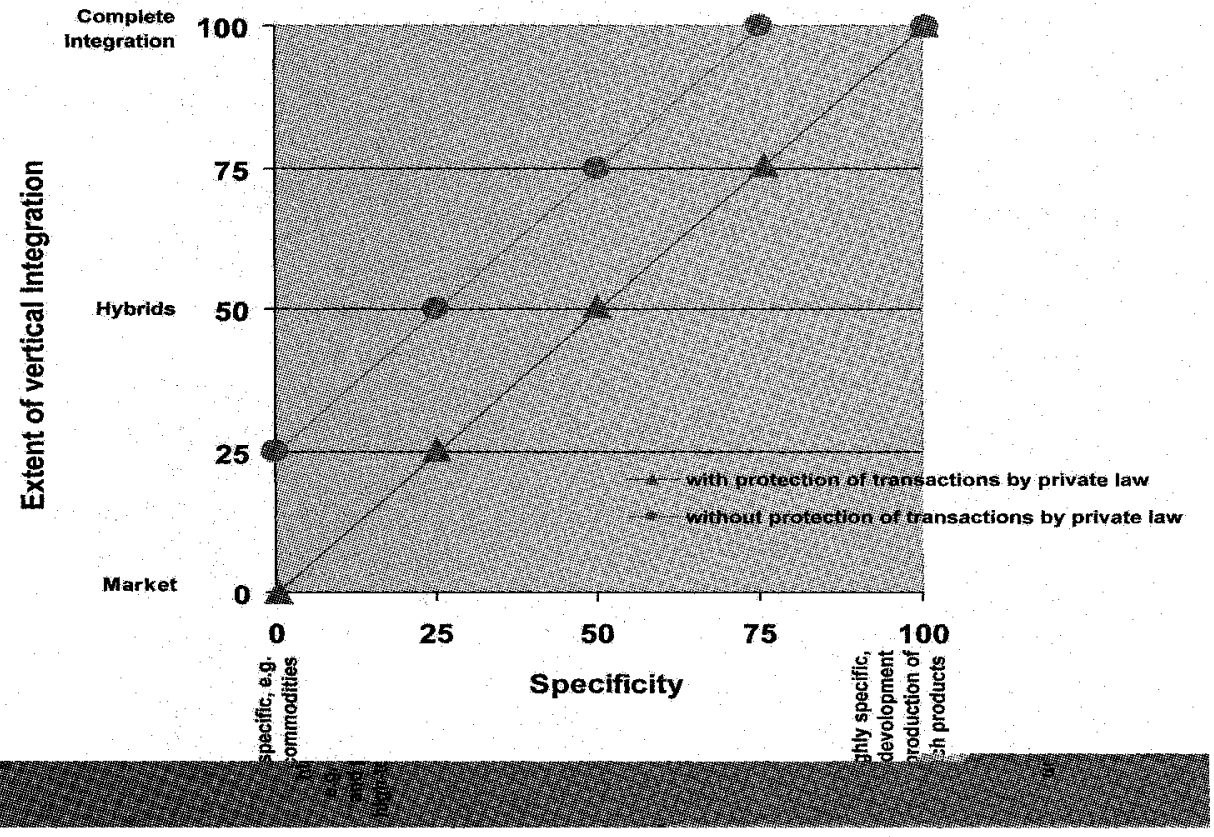

Again it is important to acknowledge that international business scholarship stresses other factors than those singled out by transaction cost analysis in explaining multinational firms. Recently, knowledgebased theories have prevailed. ${ }^{80}$ However, our thesis of an overintegration in the global market triggered by deficiencies in the institutional support framework still holds, all other possible factors influencing the make-or-buy decision in a cross-border context being equal. The remaining difficulty is in knowing how severe the problem is, a fact for which the unavailability of comparative data on the extent of vertical integration in domestic situations vis-à-vis cross-border situations is difficult to assess. ${ }^{81}$

79. Source: authors' own design.

80. See supra note 26.

81. In other words, Figure 2 above consists of ordinal, rather than interval, scales, a fact that is also true for the schema given in Williamson, supra note 13, at 12 fig.1. 


\section{Support by Research on the National Level}

However, recent analytical models and empirical tests have been presented in the economic literature and address a similar topic: the influence of national institutions surrounding the decision of whether to organize cross-border economic transactions outside or within the firm.

Grossman and Helpman present a model concerning the case of a firm in a specialized industry willing to transfer a part of its production chain abroad. They link the decision of whether to outsource the activity or choose foreign direct investment to the contracting environment in the country of destination. They formulate a negative relationship: if the contracting environment is good, a larger part of activities will be transferred abroad by outsourcing, while foreign direct investment will prevail if contracting is poorly protected. ${ }^{82}$

Drawing on a similar but more complex model, and also taking into account the choice of where to outsource or do foreign direct investment, Antràs comes to a similar conclusion:

[T]n choosing between domestic and foreign sourcing, the Northern manager $H$ faces a trade-off between the lower costs of Southern components and the higher incompletecontracting distortions associated with it . . . . Because transactions in the North are governed by complete contracts, ownership structure in Northern sourcing is both indeterminate and irrelevant. In contrast, when Southern sourcing is chosen ... the assignment of residual rights is much more interesting . . . .83

Inspired by such theoretical regression analysis, economists have conducted empirical research on the matter, testing the validity of the models by statistics on cross-border trade.

For example, Bernard, Jensen, Redding, and Schott have conducted research on the relation between the contracting environment and the boundaries of the firm by looking at the factors determining the share of intrafirm trade in the total of U.S. imports. They conclude that affiliates are more likely to be situated in countries with a good contracting

82. Gene M. Grossman \& Elhanan Helpman, Outsourcing Versus FDI in Industry Equilibrium, 1 J. EUR. ECON. ASS'N 317, 326 (2003).

83. Pol Antràs, Property Rights and the International Organization of Production, 95 AM. ECON. REV. 25, 30-31 (2005). 
environment, whereas the share of intrafirm trade is lower in countries with a poor institutional framework. ${ }^{84}$

The relationship between the quality of the contracting environment and the sourcing decision is also supported by a study from Matsuura and Ito. Having tested this issue on the Japanese crossborder trade statistics, they find that the share of imports in the form of intrafirm trade is negatively related to the quality of institutions in the country of origin. ${ }^{85}$

Supported by such contributions in the economic literature, the relation between the contracting environment and sourcing decisions has become more and more visible in the public discussion. Thus, the World Trade Organization also states in its annual report:

Another important factor in determining whether to integrate or outsource and where to offshore is the quality of the institutional framework .... The quality of institutions matters because the contract between the final good producer and the supplier of the intermediate good in the arm's-length relationship needs to be enforceable. If not, the risk of outsourcing may be too high. 86

Leaving aside details, there is a clear finding, supported by the contributions cited above, that legal institutions supporting contractual obligations are a crucial factor for the sourcing decision of firms. If the contracting environment is good, transactions will be managed on the market via outsourcing. If contracting is poorly protected, intrafirm trade is the preferred mode of organization.

The cited research projects may be concerned only with the relation between the quality of national institutions and the decision between intrafirm trade and outsourcing. However, there is a strong parallel to the central problem of this article. It is plausible to conclude from the findings on the national level that the relationship between the quality

84. Andrew B. Bernard et al., Intrafirm Trade and Product Contractibility, 100 AM. ECON. REV. 444, 448 (2010).

85. Toshiyuki Matsuura \& Banri Ito, Intra-Firm Trade and Contract Completeness: Evidence from Japanese Affiliate Firms 17 (RES. InST. OF ECON., TRADE \& INDUSTRY DISCUSSION PAPERS NO. 09-E-026 June 2009), available at http://www.rieti.go.jp/jp/ publications/dp/09e026.pdf.

86. WORLD TRADE ORG., WORLD TRADE REPORT 2008: TRADE IN a GLOBalizing WORLd

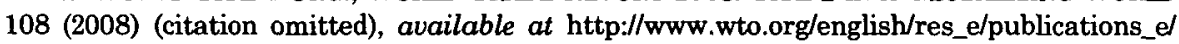
wtr08_e.htm. 
of institutions and the sourcing decision is the same on the international level.

Empirical research on the quality of institutions supporting crossborder transactions is urgently needed. However, it would be surprising if the following thesis did not hold true: Weak protection of cross-border contracting leads to a large share of intrafirm trade on international markets. Respectively, better institutions on the international level would foster the organization of cross-border transactions through market mechanisms-namely, through outsourcing.

\section{B. The Disenchantment of Vertical Integration}

How does this finding affect the assessment of vertical integration? One has to concede to the proponents of the more economic approach in European competition policy that vertical integration in cross-border transactions is indeed microeconomically efficient for the trade partners involved. This approach enables transborder economic exchange that, due to the high uncertainty of market governance, would otherwise not be conducted at all. However, it remains questionable whether the assumption can be maintained so that the so-called consumer pass-on can achieve a positive effect for national economies. ${ }^{87}$

From a macroeconomic perspective on transaction costs, the increased level of vertical integration in cross-border markets is alarming. Due to the euphoria about the potential efficiency advantages, problems arising from integrated organizational structures are underestimated.88 Hybrid governance mechanisms such as letters of credit or arbitration entail significant additional transaction costs. Trade clubs and trade intermediaries take commissions. Even to the extent that international trade is safeguarded by a transaction-specific mélange of public and private governance mechanisms, ${ }^{89}$ significant transaction costs arise in the negotiation phase through the involvement of international law firms. ${ }^{90}$ The organizational costs and friction losses of hierarchical steering of the transnational corporations discussed here are especially significant as the size of these structures is immense. By dint of the principal-agent relations within the corporate structure, friction losses emerge through the so-called X-Inefficiency. ${ }^{91}$

87. See supra Part IV.C.

88. Williamson, supra note 13 , at 11 ("[T] attended by a loss of incentive intensity and added bureaucratic costs.").

89. See Calliess, supra note 11.

90. See Sosa, supra note 11.

91. For more details on X-Inefficiency, see Harvey Leibenstein, X-Efficiency, in THE NEW PALGRAVE DictionaRY of ECONOMICS, supra note 16. 
The latter denotes the difference between the actual costs incurred and the minimally necessary costs, especially due to a lack in competition incentives and the pursuit of interests stemming from outside a company's core business. For instance, individual employees avoid sensible decisions for the corporation as a whole if those decisions jeopardize their own career or future employment. In order to strengthen their own position, synergy effects remain unutilized or lowprized external sources of supply are concealed.92 Also, heterarchical corporate networks, which are characterized by long-term contractual relations, suffer from low competition incentives and require bureaucratic efforts to maintain relations. Furthermore, the costs of network structures increase disproportionately with increasing size; with the conduct of transactions spanning very long distances, with members coming from very different cultures, it is far more difficult and costly to establish an effective reputational network. ${ }^{93}$

Due to these disadvantages, Williamson termed the firm-internal conduct of transactions as the organization form of last resort. He gives clear guidance: "try markets, try hybrids, and have recourse to the firm only when all else fails." 94 Vertical integration is only then economically beneficial and advised if the specificity, uncertainty, and frequency of transactions justify the high level of time and effort expended. Otherwise market governance is the more attractive organizational form, as it allows a leaner internal administration and offers optimal structures of incentives through competition.

The increased level of vertical integration adds bureaucratic costs through cross-border transactions. Vertical integration does enable global economic exchange-but only at high costs. Via the final price for any good or service provided across borders, the consumer pays the profit margin of private providers of hybrid governance mechanisms or transnational corporations, respectively. In order to avoid any misunderstanding, it should again be stressed that vertical integration is not unwanted per se; rather, it offers a sensible and cost-effective organizational form when the specificity, uncertainty, and frequency of transactions are high. However, the tailor-made governance solutions of transnational commerce lack the economies of scale that a stateorganized private law regime offers as a safeguard for the multitude of

92. See Paul L. Joskow, Vertical Integration, in HANDBOOK OF NEW INSTITUTIONAL ECONOMICS, supra note 52, at 319, 336.

93. However, this form of organization is made less expensive by technological developments, especially the Internet and online communication, which provide private order with a competitive edge vis-à-vis state order. See Dietz \& Nieswandt, supra note 11.

94. Williamson, supra note 13 , at 12. 
relatively unspecific transactions. ${ }^{95}$ The additional costs for increased integration ultimately must be carried by the consumer. Even if one could suspend sociopolitical concerns about power-laden economic structures, the assumption that economically efficient vertical integration always has a positive effect for the consumer in the longterm could not provide a convincing argument for cross-border constellations. Thus, it is not enough to portray vertical integration as a means for maximizing consumer welfare per se.

\section{CONSEQUENCES FOR COMPETITION POLICY}

In this final section, we draw consequences from our reasoning for the future orientation of competition policy.

\section{A. Antitrust Law: A Remedy?}

If forms of vertical integration in cross-border transactions cause concern for competition policy, can they not be prevented through the restrictive regulation of vertical agreements and mergers under antitrust law? However, this notion itself suggests that antitrust law would not go far enough due to a number of reasons.

First, it would be counterproductive. If the integration of transactions into dependency structures and corporate structures were the only possible way to generate sufficient certainty for transactions in the absence of a functioning state private law system, the ban of such structures under antitrust law would render the conduct of cross-border transactions nearly impossible. Under antitrust law, what has developed-in given circumstances-into an indispensable component of the cross-border division of labor should not be banned due to state omissions in the field of the supranational private law.

Furthermore, in practice, it could not be answered with certainty whether and to what degree the legal uncertainty of international markets is a decisive factor for the vertical integration of a concrete transaction. The decision about the most reasonable organizational form at the time of a transaction is based on a number of economic considerations; here, the institutional function of the firm as organizer of internal markets is only one factor among others. The theoretical explanatory approach of the effects of deficient state protection of private law in cross-border transactions on the structure of transborder markets is therefore not an instrument that competition authorities could apply in their practice.

95. ThOMAS DiETZ, INSTTTUTIONEN UND GLOBALISIERUNG 44-51 (2010). 


\section{B. Competition Policy Through Private Law}

Does the fact that antitrust law is not able to offer a solution for this problem lead to the conclusion that state competition policy is powerless altogether? This is certainly not the case if one moves away from the widely held equation of competition policy and competition law. An economic constitution geared toward the free market is based on several pillars: transaction law, intervention law, and regulatory law. ${ }^{96}$ Whereas transaction law safeguards property rights and contract enforcement, intervention law is concerned with the provision of public goods, for whose production the market offers no sufficient incentive. Finally, regulatory law defines the limits of state intervention into the freedom of economic subjects and guards against competition restrictions through private actors. As a component of corrective regulatory law, competition law has only a subordinate function in this structure because at the very least it requires that hypothetically competitive market structures be defended against competition restrictions. Transaction law, however, is constitutive for the formation of competitive markets. Only if the protection of property rights and the enforcement of contracts are guaranteed by transaction law will economic subjects be able to start exchanges with anonymous trade partners. Only a private law regime-which institutionalizes the course of justice and is capable of enforcing justified claims with legitimate force-allows market participants to conduct transactions beyond structures of personal dependency and hierarchy. Therefore, a functioning transaction law logically precedes competition law as part of regulatory law.

The institution of transaction law also takes precedence when applied to the area of cross-border transactions, so that considerations in competition law find a foundation in the first place. In other words, antitrust law cannot regulate the market structure as long as a market cannot emerge in the absence of transaction law. Only by dint of sufficient institutional protection can both market transactions between independent parties be made possible across borders and the level of vertical integration be lowered to a degree tenable from the perspective

96. See Peter Behrens, Die Bedeutung des Kollisionsrechts für die "Globalisierung" der Wirtschaft [The Significance of Conflict of Laws to the "Globalization"of the Economy], in AUfBRUCH NACH EUROPA: 75 JaHRE MAX-PlanCK-INSTTTUT FÜR PRIVATRECHT 384-86 (Jürgen Basedow et al. eds., 2001) (Ger.); Wolfgang Kerber \& Viktor Vanberg, Constitutional Aspects of Party Autonomy and Its Limits . The Perspective of Constitutional Economics, in PARTY AUTONOMY AND THE ROLE OF INFORMATION IN THE INTERNAL MARKET 49 (Stefan Grundmann et al. eds., 2001); Peter Behrens, Weltwirtschaftsverfassung [World Economic System], 19 JAHRBUCH FÜR NeUE POLITISChE ÖKONOMIE 5, 9 (2000) (Ger.). 
of transaction cost theory. The analysis of cross-border market structures from the viewpoint of transaction cost theory proves that, due to the high degree of vertical integration, the entire global economy incurs higher costs than necessary. In the nineteenth century, nationstates already recognized the cost benefits of the free market, although on a smaller scale. Nationalizing commercial law and free trade between independent parties beyond locally limited network structures enabled this. ${ }^{97}$ Today, the advantages of a low level of vertical integration in the economy is recognized and utilized as well. In order to save on administrative costs and to gain flexibility, corporations tend to decouple activities outside of their core competence from their hierarchy and transfer them to other companies through so-called outsourcing. However, economic analyses demonstrate that corporations tend to outsource only in those countries in which legal institutions provide sufficient enforcement of contracts with independent contractual partners. ${ }^{98}$

This highlights the need for state institutions that safeguard legal decision making and enforcement of contracts when it comes to crossborder transactions at arms' length. However, it remains beyond the scope of this article to inquire how this aim can be achieved: whether through the institution of a unitary world private law, the unification of international private law and civil procedures, or the improved cooperation of national judiciaries or similar reforms. ${ }^{99}$ It is important that, first of all, the need to act is recognized. As the reluctant unification of private law at the international and the European level shows, this need to act is currently misconceived in both disciplines. ${ }^{100}$ In order to take up the challenge of an increasingly networked world economy, the debate about vertical integration in competition policy should get rid of its blinders caused by antitrust law and engage in a symbiosis with (international) private law policy as part of competition

97. A. Claire Cutler, PrJute Power and Global authority: Transnational MERCHANT LAW IN THE GLOBAL POLITICAL ECONOMY 142 (2003).

98. See generally Gene M. Grossman \& Elhanan Helpman, Outsourcing in a Global Economy, 72 REV. ECON. STUD. 135, 137-42 (2005); Nathan Nunn, Relationship-Specificity, Incomplete Contracts, and the Pattern of Trade, 122 Q.J. ECON. 569, 594-97 (2007).

99. A plethora of suggestions for improving the state protection of private law can be found in Gralf-Peter Calliess \& Hermann Hoffmann, Effektive Justizdienstleistungen für den globalen Handel, 42 ZEITSCHRIFT FÜR RECHTSPOLITIK 1 (2009) (Ger.). For a general discussion, see Gralf-Peter Calliess \& Hermann B. Hoffmann, Judicial Services for Global Commerce - Made in Germany?, 10 GER. L.J. 115 (2009).

100. For a survey of the discussion about and the activities devoted to the unification of European private law, see Jan M. Smits, Convergence of Private Law in Europe: Towards a New Jus Commune?, in ComPaRATTVE LaW: A HANDBOoK 219 (Esin Örücü \& David Nelken eds., 2007). 
policy in a broad sense. The slogan should hence be: competition policy by dint of private law!

\section{SUMMARY}

The continuing growth of transnational corporations challenges global competition policy. To a hitherto unknown extent, such corporations are deemed too big to fail. A decisive factor in the formation of transnational corporations is the fact that, as a functional equivalent of market governance, they are able to solve external problems arising in market transactions through internal means (i.e., firms as the organizers of internal transactions).

Popularized by the more economic approach, the opinion that vertical integration not only creates benefits at the business level but also for the overall economy, and therefore vertical integration remains harmless, cannot be accepted without qualification. Against the backdrop of the particularities of cross-border transactions regarding their constitutional uncertainty, the idea of vertical integration's harmlessness cannot be unconditionally applied to the assessment of transnational corporations. In the absence of sufficient protection by a private law regime, cross-border transactions suffer from the so-called international exchange dilemma, for which the involved parties try to compensate by the increased vertical integration of their transactions. The level of vertical integration in cross-border transactions is therefore higher and, from the perspective of transaction cost theory, less justifiable than in the case of comparable domestic transactions. The transaction costs generated and ultimately borne by the consumers contradict the assumption that vertical integration benefits the consumer in the long run.

Under the current circumstances, vertical integration is a necessary means to generate sufficiently stable expectations for the conduct of cross-border transactions, and the ban of vertical integration under antitrust law would be counterproductive. The role of private law as transaction law, which constitutes competition, is misconceived in the debate about competition policy. Hence, the interdisciplinary discourse between competition policy and private law policy must be intensified in order to call attention to the need for the efficient protection of transactions by private law for efficiently functioning international market structures. 